\title{
ОСОБЕННОСТИ ФОРМИРОВАНИЯ ФИТОСАНИТАРНОЙ СИТУАЦИИ В ПОСАДКАХ ЦВЕТНЫХ СОРТОВ КАРТОФЕЛЯ И ЕГО ПРОДУКТИВНОСТЬ ПРИ РАЗЛИЧНЫХ СИСТЕМАХ ЗАЩИТЫ РАСТЕНИЙ
}

\author{
Малюга А. А., Чуликова Н. С., Енина Н. Н., Голощуапов С. А.
}

Сибирский федеральный научный иентр агробиотехнологий Российской академии наук, p.n. Краснообск, Россия, anna_malyuga@mail.ru

https://doi.org/10.53040/9789975347204.16

\begin{abstract}
Data were obtained on the peculiarities of the development of black scab on four varieties of colored potatoes (Violet, Purple Majesty, All Red and Rosamaria) when culvaed using chemical and biologized plant protection systems. It is shown, that the development of black scab and its infestation of stolons on varieties grown with the use of chemical plant protetion agents is lower than with the use of biological preparations, respectively, by $2.4-6.5$ times and by $4 \%$. The biometric indicators of plants when they were grown using the chemical protection system were slightly higher than those on biologized ones. The individual reaction of varieties to the studied protective techniques was revealed. Among the four studied cultivars, the cultivar All Red stood out, in which the phytosanitary condition of plantings, productivity indicators on both protection systems were similar.
\end{abstract}

Key words: potato, black scab, chemical and biological plant protection, productivity. 


\section{Введение}

Разработка различных приемов защиты растений, направленных на обеспечение населения РФ экологически безопасными продуктами питания, и в частности картофелем, является в настоящее время, одним из перспективных направлений исследований в облсти сельского хозяйства. Предпосадочная обработка клубней, а также обработка вегетирующих растений биопрепаратами способствует более интенсивному накоплению биомассы растениями, формированию фотоассимиляционного аппарата, повышает содержание крахмала, а также устойчивость к болезням и вредителям. В последнее время появились новые микробиологические препараты на основе уже известных бактерий и грибов. Эти препараты представляют собой живые клетки или их комплексы с метаболитами, которые находятся или в культуральной жидкости, или адсорбированы на нейтральном носителе. Они позволяют создать огромную концентрацию полезных форм микроорганизмов (в 1 г препарата может содержаться от 1 до 10 млрд. клеток бактерий или грибов), которые дставляются в нужное место и в нужное время. За счет этого внесенные формы могут успешно конкурировать с аборигенной микрофлорой и захватывать экологические ниши, обеспечивая растения целым рядом полезных функций. Использование препаратов биологической природы в картофелеводстве повышает продуктивность агроценозов, снижает химический пресс на растения и улучшает экологическую обстановку в агроценозе, позволяя получать безопасную и качественную продукцию для питания человека и животных, а также поддерживает и восстанавливает биоту почвы. В тоже время в условиях Западной Сибири, и в частности Новосибирской области, применение биопрепаратов в картофелеводстве, несмотря на их явные достоинства, минимально. Выращивание картофеля и получение высоких урожаев в настоящее время в основном связано с использованием химических средств защиты растений. Однако эффекты пестицидов не однозначны: эти вещества могут быть токсичными, канцерогенными и мутагенными. В тоже время биопрепараты обладают ярко выраженной избирательностью действия, быстро разлагаются в почве, воде, под действием солнечных лучей, не вызывают, в отличие от химических препаратов, эффекта резистентности. Поэтому одним из направлений совершенствования производства картофеля, его качества, стабилизации фитосанитарного состояния посадок картофеля может стать расширение сортимента биологических препаратов и совершенствование приемов их использования.

В связи с изложенным, целью исследований являлась разработка экологически безопасной системы защиты картофеля от вредных организмов в условиях лесостепи Приобья.

\section{Материалы и методы}

Исследования проведены в почвенно-климатических условиях типичны для лесостепной зоны Западной Сибири. Основные элементы технологии возделывания картофеля соответствуют общепринятым для данного региона [1].

Для исследований взяты цветные сорта: Фиолетовый, Purple Majesty, All Red и Rosamaria. Наблюдения за динамикой ризоктониоза проведены на естественном фоне по общепринятым методикам [2, 3].

В биологизированной системе защиты картофеля для оптимизации фитосанитарного состояния посадок в отношении почвенно-клубневых возбудителей болезней семенной материал обработан перед посадкой биопрепаратом Бактофорт, Ж (содержание живых клеток бактерий Bacillus subtilis, B. amiloliquefaciens (не менее 5,0 х $10^{9} \mathrm{KOE/мл} \mathrm{жизнеспособных} \mathrm{клеток} \mathrm{к} \mathrm{концу} \mathrm{хранения,} \mathrm{норма} \mathrm{расхода} \mathrm{2,0-2,5} \mathrm{л/т).} \mathrm{Для}$ 
защиты посадок от листо-стебельных также применен биофунгицид Бактофорт, Ж (норма расхода 2,0-3,0 л/га) - интервал между обработками 7-10 дней, кратность 2-3 раза, по первым симптомам или профилактически. При химической системе посадки защищены от почвенно-клубневых инфекций путем весеннего протравливания посадочных клубней инсектицидом на основе тиаметоксама, дифеноконазола и флудиоксонила (Селест Топ, КС 262,5 г/л + 25 г/л + 25 г/л, норма расхода 0,4 л/т). От листостебельных - фунгицидом на основе дифеконазола и мандипропамида (Ревус Топ, СК 250,0 г/л + 250,0 г/л, норма расхода 0,6 л/га).

В обеих системах защиты контроль над сорными растениями осуществлен с помощью гербицидов на основе метрибузина (Метрифар 70, ВГ, 700 г/кг, норма расхода 0,7-1,4 л/га) и просульфокарба (Боксер, КЭ, 800 г/л, норма расхода 3-5 л/га) [36]. Помимо этих препаратов, по вегетации после цветения, культура 3 раза обработана (с интервалом 10-15 дней) комплексным водорастворимым микроудобрением Полигро Универсал (N19-P19-K19+1 Mg+ 0,02 B, 0,011 Cu, 0,130 Fe, 0,05 Mn, 0,007 Mo, 0,015 Zn, норма расхода 5-6 кг/га) для полноценного и сбалансированного питания культуры, повышения иммунитета и стрессоустойчивости растений.

Результаты опытов обработаны с применением пакета прикладных программ СНЕДЕКОР [4].

\section{Результаты и обсуждение}

Исследования показали, что развитие ризоктониоза на сортах выращиваемых с применением химических средств защиты растений существенно ниже, чем при использовании биопрепаратов (табл. 1). Данный показатель в среднем по системам был ниже в 6,5 раз в фазу всходов, и в 2,4 раза - в период созревания культуры. Пораженность столонов возбудителем ризоктониоза картофеля также была ниже при использовании химического протравителя Селест Топ в сравнении с биологическим препаратом Бактофорт, но эта разница была незначительной, и составила в среднем за вегетацию 3,6-3,7\%.

Биометрические показатели растений на химической системе защиты были выше, чем на биологизированной. В среднем по системе длина стеблей в фазу всходов и масса одного растения в период созревания были достоверна выше при выращивании растений с помощью химических пестицидов.

Пробные копки показали, что в среднем скорость клубнеобразования и клубненакопления имеет небольшую, но существенную разницу в пользу химической системы защиты.

Следует также отметить индивидуальную реакцию сортов на изученные защитные приемы. Так среди четырех изученных сортов, следует выделить All Red, y которого развитие ризоктониоза на стеблях и показатели продуктивности на обеих системах защиты были близки.

Таблица 1 - Влияние различных систем защиты на ризоктониоз и показатели продуктивности культуры на различных сортах цветного картофеля (2020 г.)

\begin{tabular}{|c|c|c|c|c|c|c|}
\hline Сорт & $\begin{array}{c}\text { Развитие } \\
\text { болезни, } \\
\%\end{array}$ & $\begin{array}{c}\text { Столоны } \\
\text { пораженные } \\
\text { ризоктонией, } \%\end{array}$ & $\begin{array}{c}\text { Длина } \\
\text { стебля, } \\
\text { см }\end{array}$ & $\begin{array}{c}\text { Масса, } \\
\text { г/1 } \\
\text { раст. }\end{array}$ & $\begin{array}{c}\text { Количество } \\
\text { клубней, } \\
\text { шт./ 1 раст. }\end{array}$ & $\begin{array}{c}\text { Масса } \\
\text { клубней, } \\
\text { г/1 раст. }\end{array}$ \\
\hline \multicolumn{7}{|c|}{ Химическая система защиты } \\
\hline Purple Majesty & 0 & 0 & 33,9 & 167,5 & - & - \\
\hline Фиолетовый & 7,3 & 0 & 29,0 & 176,2 & - & - \\
\hline
\end{tabular}




\begin{tabular}{|c|c|c|c|c|c|c|}
\hline All Red & 6,2 & 0 & 32,7 & 186,2 & - & - \\
\hline Rosamaria & 12,5 & 0 & 46,1 & 225,0 & - & - \\
\hline Средние & 6,5 & 0 & 35,4 & 188,7 & - & - \\
\hline \multicolumn{7}{|c|}{ Биологизированная система защиты } \\
\hline Purple Majesty & 51,9 & 24,7 & 30,6 & 197,5 & - & - \\
\hline Фиолетовый & 84,2 & 54,6 & 29,1 & 151,2 & - & - \\
\hline All Red & 10,8 & 2,5 & 29,2 & 105,0 & - & - \\
\hline Rosamaria & 21,8 & 14,0 & 42,8 & 228,7 & - & - \\
\hline Средние & 42,2 & 23,9 & 32,9 & 170,6 & - & - \\
\hline $\mathrm{HCP}_{05}$ & 2,6 & & 1,9 & 21,4 & - & - \\
\hline \multicolumn{7}{|c|}{ Фаза созревания } \\
\hline \multicolumn{7}{|c|}{ Химическая система защиты } \\
\hline Purple Majesty & 18,3 & 3,6 & 61,9 & 495,0 & 8,5 & 285,0 \\
\hline Фиолетовый & 15,1 & 4,2 & 69,3 & 587,5 & 8,2 & 282,5 \\
\hline All Red & 8,7 & 5,4 & 52,3 & 227,5 & 6,5 & 520,0 \\
\hline Rosamaria & 14,1 & 1,8 & 70,1 & 400,0 & 12,5 & 407,5 \\
\hline Средние & 14,0 & 3,7 & 63,4 & 427,5 & 8,9 & 373,7 \\
\hline \multicolumn{7}{|c|}{ Биологизированная система защиты } \\
\hline Purple Majesty & 23,7 & 15,6 & 64,1 & 330,0 & 7,7 & 185,0 \\
\hline Фиолетовый & 45,8 & 35,6 & 63,4 & 450,0 & 5,2 & 200,0 \\
\hline All Red & 15,6 & 31,7 & 50,3 & 250,0 & 8,0 & 552,5 \\
\hline Rosamaria & 31,2 & 17,0 & 73,4 & 465,0 & 12,5 & 363,7 \\
\hline Средние & 32,9 & 27,5 & 62,1 & 373,7 & 8,3 & 325,3 \\
\hline $\mathrm{HCP}_{05}$ & 1,7 & & 15,0 & 25,3 & 0,5 & 29,8 \\
\hline
\end{tabular}

\section{Выводы}

Таким образом, для борьбы с ризоктониозом картофеля в условиях лесостепи Пробья. возможно использовать биологизированные системы защиты при его возделывнии, но с учетом биологических особенностей сортов. Сочетание толерантного сорта и биологических препаратов позволит получить экологически безопасный продукт должного качества

\section{Библиография}

1. Овощные культуры и картофель в Сибири / РАСХН. СибНИИРС. ГНУ Сиб. рег. отд.; сост.: Г.К. Машьянова, Е.Г. Гринберг, Т.В. Штайнерт. Новосибирск, 2010. С. 496-507. 2. Методика исследований по культуре картофеля. М.: НИИКХ, 1967. 264 с.

3. Frank J., Leach S.S., Webb R.E. Evalution of potato clone reaction to Rhizoctonia solani // Plant dis. reporter. 1976. V. 60, № 11. P. 910-912.

4. Сорокин О.Д. Прикладная статистика на компьютере. 2-е изд. Новосибирск, 2012. $282 \mathrm{c}$. 